\title{
List of publications by Prof. Dr. A. C. Schuffelen
}

Schuffelen, A. C., 1930. Geneesmiddelen, Jaarboek Oud Studentenvereniging St. Joris, 1930.

Schuffelen, A. C., 1931. Gekleurde additie verbindingen. Ons Orgaan, juli 1931.

Schuffelen, A. C., 1932. De verhouding tussen voedingswaarden en prijs van levensmiddelen. Ons Orgaan, mei 1932.

Schuffelen, A. C., 1938. Bodem en plant, A.S.F. Nieuws 9: 166.

Schuffelen, A. C., 1939. Wageningen. Gasspecialist 1: 92.

Schuffelen, A. C., 1939. Het fosfaation. A.S.F. Nieuws 10: 194.

Schuffelen, A. C., 1940. De quantitatieve analyse met vlamspectra en hare nauwkeurigheid. Doctor's thesis, Utrecht, pp. 158.

Schuffelen, A. C., 1940. Is de plantengroei afhankelijk van de ionenverhouding in de grond? II. De ionenverhouding in de grond en de rendabiliteit der meststoffen, Landbouwk. Tijdschrift 52: 845-868.

Hulst, L. J. N. van der \& A. C. Schuffelen, 1941. De alcaliteit van waschmiddelen. II. Over de meting van de $\mathrm{pH}$ van eenige componenten bij $85^{\circ} \mathrm{C}$. Chem. Weekbl. 38: 134-140.

Schuffelen, A. C. \& L. J. N. van der Hulst, 1941. De alcaliteit van waschmiddelen. III. Over de betrekking tussen de concentratie en de $\mathrm{pH}$ der waschvloeistof. Chem. Weekbl. 38: 231-234.

Hulst, L. J. N. van der \& A. C. Schuffelen, 1941. De alcaliteit van waschmiddelen. IV. Over de samenstelling en buffercapaciteit van eenige waschalcaliën. Chem. Weekbl. 38: 491-496.

Schuffelen, A. C., 1941. Eenige in de Landbouwscheikunde toegepaste micro-chemische methoden. Chem. Weekbl. 38: 604-609.

Loosjes, R. \& A. C. Schuffelen, 1941. Ion activities in suspensions (Preliminary notes). Proc. Ned. Akad. Wet. 44: 475-482.

Schuffelen, A. C. \& R. Loosjes, 1942. De kinetica der kaliumopname (Een toepassing van radioactieve indicatoren). Landbouwk. Tijdschr. 54: 22-28.

Schuffelen, A. C. \& R. Loosjes, 1942. The importance of the growth medium for the absorption of cations by plants (A working hypothesis). Proc. Ned. Akad. Wet. 45: 726-733.

Schuffelen, A. C. \& R. Loosjes, 1942. The influence of the ion activity and the ion concentration in the medium on the absorption of cations by plants. Proc. Ned. Akad. Wetensch. 45: 944-952.

Domingo, W. R. \& A. C. Schuffelen, 1942. Landbouwscheikundig onderzoek en planteveredeling. Landbouwk. Tijdschr. 54: 457-474.

Hudig, J., A. C. Schuffelen \& B. W. G. Wittewaal, 1942. De waarde van het oriënterend grondonderzoek bij ontginnings- en herontginningswerkzaamheden. Tijdschr. Ned. Heidemij 54: 262-268.

Hudig, J. \& A. C. Schuffelen, 1942. De betrouwbaarheid, nauwkeurigheid en kostprijs der analyse bij het landbouwkundig onderzoek. (Reliability, exactness and expenses of analysis in agricultural research), Landbouwk. Tijdschr. 54: 772-790.

Loosjes, R. \& A. C. Schuffelen, 1943. Invloed van het milieu op de kationenopname door planten en wortels. Hand. 29 e natn. Geneesk. Congr.: 177-181.

Schuffelen, A.C., 1944. De bodumkundige factoren die de opneming van kalium door de plant beinvloeden. Landbouwk. Tijdschr. 56: 116-124.

Schuffelen, A. C., J. Hudig \& B. W. G. Wittewaall, 1945. Scheikundige verschillen in de bouwvoor in horizontale richting en op korte afstand. Landbouwk. Tijdschr. 56-57: 457-465.

Schuffelen, A. C., 1946. Grondonderzoek. I. Over de werkzame concentratie der voedingselementen in den grond. Landbouwk. Tijdschr. 58: 367-376.

Schuffelen, A. C., 1946. Het amerikaanse snelle onderzoek van grond en gewas. Meded. Dir. Tuinb.: 531-536.

Schuffelen, A. C. \& T. Barendregt, 1946. The activity of several cations in Dusarite suspensions. Recl. Trav. chim. Pays-Bas 65: 807-815.

Schuffelen, A. C. \& R. Loosjes, 1946. The importance of the ion activity of the medium on the root potential for the cation absorption by the plant. Proc. Kon. ned. Akad. Wet. 49: 80-86.

Edelman, C. H. \& A. C. Schuffelen, 1947. On the origin of some clay minerals in soils, C.r. Conf. Pedol. méditerr.: 109-113.

Schuffelen, A. C., 1947. Uw tuin binnenshuis - de watercultuur van planten. Vrij Nederland, 15 november, 1947.

Schuffelen, A. C., 1947: Het onderwijs in de bodemkunde van de Landbouwhogeschool te Wageningen, Prae-advies Nederlandse Bodemkundige Vereniging (november).

Schuffelen, A. C., 1947. Kunst- of natuurmest. Maandbl. LandbVoorlDienst 4: 413-420. 
Schuffelen, A. C., 1947. De grondslagen van het bemestingsadvies. Openbare les gehouden bij de aanvaarding van het ambt van lector aan de Landbouwhogeschool op 5 februari 1947. Veenman. Wageningen, pp. 20.

Schuffelen, A. C. \& P. H. Dal, 1947. Over de wet der massawerking. I. Chem. Weekbl. 43: 297-300.

Schuffelen, A. C., 1948. Over de vruchtbaarheid van de bodem. Chem. Weekbl. 44: 146-153.

Schuffelen, A. C., 1948. Nieuwe phosphaat-meststoffen. Chem. Weekbl. 44: 238-240.

Schuffelen, A. C., 1948. Over de interpretatie van de resultaten van grondonderzoek. Meded. Landb. Hogesch. OpzoekStns Staat Gent 13: 169-172.

Schuffelen, A. C., 1948. Plantengroei, ionenabsorptie en ionenverhouding. Agricultura 46: 1-23.

Schuffelen, A. C., 1948. Growth substance and ion absorption. PI. Soil 1: 121-126.

Schuffelen, A. C., 1948. Over het selecterend vermogen van de plant voor ionen. Vlaams Natuurwet. Tijdschr. 30: 65-72.

Schuffelen, A. C., 1949. Rondom het bemestingsbeleid. Rede uitgesproken bij de aanvaarding van het ambt van hoogleraar in de landbouwscheikunde aan de Landbouwhogeschool te Wageningen op 28 october 1949 . Veenman, Wageningen, pp 18.

Schuffelen, A. C., 1949. Bemestingsproblemen in verband met bodemtypen. Bodemk. Voordr., Landb. 9: 112-123.

Schuffelen, A. C., 1949. De vruchtbaarheid van de grond in het bijzonder de lucht- en waterhuishouding. Bodemk. Voordr., Landbouw 9: 5-20.

Schuffelen, A. C., 1950. Prof. Ir. Hudig. Landbouwk. Tijdschr. 62: 219-221.

Schuffelen, A. C. \& G. H. Bolt, 1950. Some notes on the synthesis of humus compounds. Landbouwk. Tijdschr. 62: 333-338.

Schuffelen, A. C. \& J. van Schuylenborgh, 1950. Het gebruik van de methode Vilenski ter bestudering van de invloed van de vorst en van de micro-organismen op de structuur van de grond. Landbouwk. Tijdschr. 62: 339-347.

Schuffelen, A.C., 1950. On the cation absorption of plants in relation to the composition of the soil adsorbing complex. Trans. 4th int. Congr. Soil Sci. (Amsterdam) Vol. 2: 163-165.

Schuffelen, A. C., 1950. Over de scheikunde van de humus. Maandbl. Landb.Voorl.Dienst 76: $213-218$.

Schuffelen, A.C., 1950. Het chemisch onderzoek van grond en gewas (Chemical analysis of soil and crops). Meded. Dir. Tuinb. 13: 735-744.

Schuffelen, A. C., 1950. Het meten van de waterstofionenconcentraties. Chem. Weekbl. 46: 898-902.

Schuffelen, A. C., 1950. De sporenelementcommissie T.N.O. T.N.O.-Nieuws 6: 13-18.

Schuffelen, A. C., 1950. Manurial experimentation in the manufacturing industry of and trade in fertilizers in the Netherlands. Proc. 4th int. Congr. Soil Sci.: 13-15.

Schuffelen, A. C., 1950. The Agricultural University College, Wageningen. Proc. 4th int. Congr. Soil Sci.: 16-18.

Schuffelen, A. C., 1951. Grondonderzoek. Kali 8: 184-189.

Schuffelen, A. C. \& J. van Schuylenborgh, 1951. Het vastleggen van phosphaat aan kaoliniet (The fixation of phosphate kaolinite). Landbouwk. Tijdschr. 63: 164-167.

Schuffelen, A. C., 1951. Toespraak bij gelegenheid van de installatie der sporenelementencommissie T.N.O. T.N.O.-Nieuws 6: 13-17.

Schuffelen, A. C., 1951. Organisation, means and form of publicity for fertilizers and agents for improving the soil. Proc. 2nd Fertilizer World Congr. (Rome).

Schuffelen, A. C., 1951. The problem of the secondary elements: Magnesium. Proc. 2nd Fertilizer World Congr. (Rome).

Schuffelen, A. C., 1952. De betekenis van 'tracers' bij het bemestingsonderzoek (The importance of tracers in manurial investigations). Meded. Dir. Tuinb. 15: 610-624.

Schuffelen, A. C., 1952. Soil fertility ion intake, ion activity and ion exchange. Trans. Comm. II and IV. Int. Soil Sci. Soc. (Dublin) 1: 180-188.

Schuffelen, A. C., J. J. Lehr \& M. Rosanow, 1952. The technique of pot experiments. Trans. Int. Soc. Sci. (Dublin) 2: 263-268.

Schuffelen, A. C., 1952. Krilium. Fruitteelt 42: 457.

Schuffelen, A. C. \& H. A. Middelburg, 1953. Ionic exchange interrelationships in soils and crops. I. Ion selectivity in soils. Neth. J. agric. Sci. 1: 97-110.

Schuffelen, A. C., 1953. Extension methods and prerequisites suitable for Dutch conditions in the field of soils and fertilizers. Meth. agric. Extension, Wageningen 323-330.

Schuffelen, A. C. \& H. A. Middelburg, 1953. Enkele resultaten van een permanent bemestingsproefveld. Meded. Inl. Bureau Chilisalpeter 11: 3-10.

Schuffelen, A. C., 1954. De ontwikkeling van het humusonderzoek. Landbouwk. Tijdschr. 66: 274-280.

Schuffelen, A. C., 1954. Iets over de organische chemie van de humus. Landbouwk. Tijdschr. 66: 385-391. 
Schuffelen, A. C., A. R. P. Janse \& G. P. Wiersma, 1954. Een eenvoudige methode om het koolzuurgehalte van bodemlucht te bepalen (A rapid method for the determination of the carbondioxyde in soil air). Landbouwk. Tijdschr. 66: 36-39.

Schuffelen, A. C., 1955. The absorption of potassium by the plant. Potassium Symp. 1954: 169-181.

Schuffelen, A. C., 1955. Is er een keerzijde aan de kunstmestmedaille. T.N.O. Nieuws 116: $493-499$. Fruitteelt 45: $950-953$.

Schuffelen, A. C. \& H. A. Middelburg, 1955. Structural deterioration of lateritic soils through liming. C.r. Ve Congr. int. Sci. Sol (Leopoldsville, 1954) 2: 158-165.

Schuffelen, A. C. \& H. A. Middelburg, 1955. A rapid method for the determination of the base exchange capacity of plant roots. C.r. Ve Congr. int. Sci. Sol (Leopoldsville, 1954) 2: 348-351.

Schuffelen, A. C. \& H. W. van der Marel, 1956. Potassium fixation in soils. Potassium Symp. 1955: 157-201.

Schuffelen, A. C., 1956. Atoomenergie en landbouw. Landbouwk. Tijdschr. 68: 253-271.

Schuffelen, A. C., 1956. Het produktiesysteem plant-grond. Het chemisch vruchtbaarheidsonderzoek. Den Haag, p. 61-73.

Schuffelen, A. C., 1957. Spectraalanalyse van sporenelementen. Landbouwk. Tijdschr. 69: 546-553.

Schuffelen, A.C., 1958. De toepassing van radioactieve stoffen in het landbouwkundig onderzoek. Lustrum-nummer L.H., Handelsblad 5 mrt. 1958.

Schuffelen, A. C., 1958. Die Mineraldüngung als Voraussetzung für die Umwandlungsmöglichkeiten von 'Naturböden' in 'Kulturböden'. Gen. Ber. III. Weltkongr. Dïngungsfragen (Heidelberg, 1957): 46-57.

Schuffelen, A. C., 1958. Algemene inleiding voor voordrachten van de A-cursus 1957 over 'de toepassing van de atoomenergie in de landbouw'. Landbouwk. Tijdschr. 70: 245-248.

Schuffelen, A. C., 1958. Enkele aantekeningen over een studiereis naar de Verenigde Staten van Amerika over de toepassing van atoomenergie in de landbouw. Landbouwk. Tijdschr. 70: 370-376.

Schuffelen, A. C. \& G. H. Bolt, 1958. Ionic equilibria in soils. Bodenk. Congr. Hamburg, 2: 131-146.

Schuffelen, A. C., 1959. Radio isotopes in soil research. Application of atomic Science in agriculture and Food. II. O.E.E.C., Paris, p. 75.

Schuffelen, A. C., 1959. Atoom en Landbouw. Contact (Huisorg. PlZiektenk. Dienst Wageningen) 14: 129.

Bolt, G. H., A. R. P. Janse \& A. C. Schuffelen, 1959. Definition and determination of soil structure. International Symposium on Soil Structure (Gent, 1958), Meded. LandbHogesch. Staat Gent 24 (1958): 251-256.

Koenigs, F. F. R. \& A. C. Schuffelen, 1960. Mathematical treatment of aggregate-stability determinations. Trans. 7th int. Congr. Soil Sci. (Madison) 1: 265-271.

Schuffelen, A. C., 1960. De toepassing van isotopen bij het landbouwkundig onderzoek. Stikstof 3: 105-106.

Schuffelen, A. C., 1960. The behaviour of radio active contaminants in soils. Suppl. Radio-active materials in food and agriculture. Rome, p. 182-217.

Schuffelen, A. C., 1961. Enkele problemen rondom kali-bemesting. Kali 50: 356-360.

Schuffelen, A. C., A. Muller \& J. Ch. van Schouwenburg, 1961. Quick-tests for soil and plant analysis used by small laboratories, Neth. J. agric. Sci. 9: 2-16.

Schuffelen, A. C., 1961. Radioactieve besmetting van bodem en gewas. In: Mens, plant, dier en radioactieve besmetting. Pudoc, Wageningen. p. 97-110.

Schuffelen, A. C. \& F. F. R. Koenigs, 1962. Plant nutrients in soils of different genesis. Trans. Soil Conf. New Zeal., Comm. IV and V: 3-18.

Schuffelen, A. C., 1962. On the radioactive contamination of soils and crops. Proceedings of a Seminat on Agriculture and Public Health Aspects of Radiation Contamination in Normal and Emergency Situations, 68-91.

Schuffelen, A. C., 1962. The application of isotopes to studies in soil fertility. Soii Plant, J. Yugoslav Soc. Soil Sci. 11: 505-522.

Schouwenburg, J. Ch. van \& A. C. Schuffelen, 1963. Potassium-exchange behaviour of an illite. Neth. J. agric Sci. 11: 13-22.

Schuffelen, A. C., F. F. R. Koenigs \& G. H. Bolt, 1964. The isolation of the soil solution with the aid of filter paper tablets. Proc. 8th int. Congr. Soil Sci. (Bucharest) 3: 519-528.

Schuffelen, A. C., 1964. Kali in Illitreichen Böden. Kalibriefe, Febr. 1964, pp. 5.

Schuffelen, A. C., 1964. In memoriam Prof. Dr. C. H. Edelman. Wagenings Hogesch. Blad 11, 15 juni 1954.

Schuffelen, A. C., 1965. Kunstmest voor voedsel. Diesrede Landbouwhogeschool, 1965.

Schuffelen, A. C., M. Rosanow \& A. van Diest, 1965. Plant composition and mineral nutrition. Symp. C.I.C.R.A., Paris: 1-16. 
Schuffelen, A. C., 1965. Antwoord 65. Ceres 56: 7.

Poelstra, P., M. J. Frissel \& A. C. Schuffelen, 1965. A Sr-90 survey in the Netherlands presenting a relation between the contamination of soil and grass. Pl. Soil 23: 171-180.

Diest, A. van \& A. C. Schuffelen, 1966. Uptake of manganese by oats and sun-flowers. Trans. Comm. II and IV, Int. Soc. Soil Sci. (Aberdeen): 281-288.

Schuffelen, A. C., 1968. Een wereldomvattend grondonderzoek. Lezingen gehouden bij het veertig-jarig jubileum van het Bedrijfslaboratorium voor Grond- en Gewasonderzoek, Oosterbeek op 27 en 28 februari te Arnhem, p. 3-14.

Schuffelen, A. C., 1968. Presidential address, Symposium nitrogen in soil. Stikstof 12: 4.

Levi, J. F., A. F. Groneman \& A. C. Schuffelen, 1968. Répertoire bibliografique général des études sur la nutrition minérale et sur la fertilisation de la vinge, publiées de 1942 à 1966. Le controle de la fertilisation des plantes cultivées. Coloq. eur. mediterr. (Sevilla, Espana).

Schuffelen, A. C., 1969. Plaats en taak van de kunstmestindustrie. Polytech. Tijdschr., Ed. Procestech. 24: 732-737.

Schuffelen, A. C. 197\%. Nährstoffvorat und Nährstofflieferung im Boden. In: Chemie und Landwirtschaftliche Produktion, p. 27-42.

Schuffelen, A. C., 1972. The cation exchange system of the soil. Proc. 9th Coll. Int. Potash Inst. (Bern): 3-16.

Schuffelen, A. C. \& P. Buringh, 1973. Enkele notities bij de methode van groenbemesting van Van det Meulen. Vakbl. Biol. 53: 180.

Schuffelen, A. C., 1974. A few aspects of 50 years of soil chemistry. Geoderma, Jubilee-issue.

Schuffelen, A. C., 1974. Aspects of potassium and magnesium uptake by oats. Neth. J. agric. Sci. 22: 237-244.

Schuffelen, A. C., 1975. Energy balance in the use of fertilizers. Span, spring 1975 (in press). 